\title{
Yemlere kestane ve mimoza tanen ekstraktı ilavesinin bazı in vitro rumen fermentasyon parametreleri üzerine etkileri
}

Effects of chestnut and mimosa tannin extract supplementations to feeds on some in vitro rumen fermentation parameters

\author{
Uğur DOĞAN ${ }^{1}$ (D), Mevlüt GÜNAL ${ }^{1} \mathscr{D}$ (D) \\ ${ }^{1}$ Isparta University of Applied Sciences, Department of Animal Sciences, Faculty of Agriculture, Isparta, TURKEY.
}

MAKALE BILGISI / ARTICLE INFO

\section{Makale tarihçesi / Article history:}

DOI: $10.37908 /$ mkutbd. 720879

Geliş tarihi / Received:15.04.2020

Kabul tarihi/Accepted:15.06.2020

\section{Keywords:}

Tannin extract, feeds, in vitro rumen fermentation.

\footnotetext{
Corresponding author: Mevlüt GÜNAL

$\varangle:$ mevlutgunal@isparta.edu.tr
}

\author{
Ö ZET / A B STR A C T
}

Atıf / Citation: Doğan U, Günal M (2020) Effects of chestnut and mimosa tannin extract supplementations to feeds on some in vitro rumen fermentation parameters. MKU. Tar. Bil. Derg. 25(3) : 341-351. DOI: 10.37908/mkutbd.720879

\section{GiRiş}

Bitki dokularında yer alan tanenler polifenolik bileşiklerdir. Hidrolize ve kondense tanen olmak üzere iki ana gruba ayrılmaktadır. Hidrolize tanenler; fenolik asit, glikoz ve quinik asidin poliesterleri olup suda çözünebildiği halde, kondense tanenler; flavan-3-ol'un yoğunlaşmasıyla oluşmuştur (McSweeney ve ark., 2001). Bazı meşe, kestane, ökalüptus, çam türlerinin yaprak ve sürgünleri \% 20 ye kadar hatta \% 50'ye kadar hidrolize tanenleri içerebildiği, buna karşın, kondense tanenlerin hidrolize tanenlere göre daha geniş bir yayılım gösterdiği 
bildirilmektedir (Reed, 1995; Lowry ve ark., 1996). Ilıman ve tropikal baklagil otları \% 0-5 oranında kondense tanen içermektedir. Örneğin gazal boynuzu ( \% 2-5), korunga ( $\%$ 2-4), sulla (ispanyol korungası) (\% 2-4), Sericea lespedeza (bir çeşit labada türü) (6-7 \%) kondense tanen içermektedir (Reed, 1995; Lowry ve ark., 1996; Min ve ark., 2003).

Tanenlerde bulunan fenolik hidroksil gruplar yemlerdeki besin maddeleriyle, özellikle proteinlerle, bileşik oluşturma eğilimindedirler. Düşük düzeydeki tanenin şişmeyi önlediği, proteinlerin bypass özelliğini artırdığı, buna karşın yüksek düzeydeki tanenin ise yem tüketimini düşürdüğü, rumen mikrobiyal faaliyeti kısıtladığı, sindirim sistemindeki enzimlerinin aktivitelerini düşürerek yada besin maddeleri ile bileşik oluşturarak onların sindirilme derecesini düşürdüğü, sindirim sisteminde bazı organlarda dejenerasyona sebep olduğu ve besin maddelerinin emilimini kötüleştirdiği bildirilmektedir (McSweeney ve ark., 2001; Tabacco ve ark., 2006). Çoğunlukla kestane, mimoza ve quebracho ağaçlarından elde edilen tanenlerin ekstraktları genellikle dericilik ve boyacılık dışında şarap ve biranın berraklaştırılmasında, petrol kuyularındaki sondaj çamurunun akışkanlığının artırımasında ve buhar kazanlarının çeperlerinde birikinti oluşumunun engellenmesinde kullanılmaktadır. Hayvan yemlerine tanen ekstraktlarının yem katkı maddesi olarak katılmasına yönelik ilgi gün geçtikçe artmaktadır (Tabacco ve ark., 2006; Krueger ve ark., 2010; Jayanegara ve ark., 2012; Min ve ark., 2014).

Bu çalışmada, hidrolize tanen kaynağı olarak kestane tanen ve kondense kaynağı olarak tanen mimoza tanen ekstraktı kullanımının in vitro gaz üretimi, kuru madde sindirimi ve rumen fermentasyonuna etkileri araştırılmaya çalışılmıştır.

\section{MATERYAL ve METOT}

\section{Yem ve Hayvan Materyali}

Araştırmanın yem materyalini, \% 60 kaba yem (yonca, mısır silajı, buğday samanı) \% 40 yoğun yem (arpa, ayçiçeği küspesi) içeren yem karması (toplam karma rasyon) oluşturmuştur (Çizelge 1). Rumen içeriği aynı yemle beslenen (\% 60 kaba yem, \% 40 yoğun yemi) laktasyondaki iki baş Holstein inekten alınmıştır. Yem materyali in vitro gaz üretim tekniği uygulanmadan önce $55{ }^{\circ} \mathrm{C}^{\prime}$ de 48 saat ön kurutmaya tabi tutulmuş ve $1 \mathrm{~mm}$ elekten geçecek şekilde öğütülmüştür.

Üretici firmanın beyanına göre kestane (Castanea sp.) tanen ekstraktı (FARMATAN 75- Tanin Sevnica, Slovenya) \% 74 hidrolize tanen; mimoza (Mimosa tenuiflora) tanen ekstraktı (Mimosa Wattle Bark Extract- Teka KimyaTuzla-istanbul) \% 50.7 kondense tanen içermektedir.

\section{In vitro Gaz Üretim Tekniğinin Uygulanması}

Yem materyalinin in vitro koşullarda değerlendirilmesinde Menke ve ark. (1979) tarafından bildirilen in vitro gaz üretim tekniği kullanılmıştır. Gaz üretim miktarının saptanmasında $100 \mathrm{ml}$ 'lik özel cam tüplere (Model Fortuna, Häberle Labortechnik, LonseeEttlenschie $\beta$, Germany) dört paralel olarak mimoza ve kestane tanen ekstraktının farklı dozları $(0,25,50$ ve 75 $\mathrm{g} / \mathrm{kg}$ kuru madde (KM)) konarak, yem örneği ile yaklaşık 200 $\pm 10 \mathrm{mg}$ 'a tamamlanmıştır. Daha sonra üzerine Menke ve ark. (1979)'nın bildirdiği yönteme göre hazırlanan rumen sıvısı/tampon çözeltisinden $30 \mathrm{ml}$ ilave edilmiştir. Daha sonra tüpler $39^{\circ} \mathrm{C}^{\prime}$ deki su banyosunda fermentasyona bırakılmışlar ve sırasıyla 3, 6, 12, 24, 48, 72 ve 96 . saatlerde fermentasyonla oluşan gaz miktarları saptanmıştır.

Zamana bağlı olarak gaz üretim parametreleri Orskov ve McDonald (1979) tarafından önerilen $y=a+b$ (1-e-ct) modeli kullanılarak $a, b$ ve $c$ değerleri NEWAY adlı PC paket program yardımıyla hesaplanmıştır.

$y=$ Herhangi bir $\mathrm{t}$ anındaki üretilen gaz miktarı ( $\mathrm{ml}$ )

$a=$ Kolay bir şekilde fermantasyona uğramış kısımdan elde edilen gaz miktarı $(\mathrm{ml})$

$b=$ Yavaş bir şekilde fermantasyona uğramış kısımdan elde edilen gaz miktarı ( $\mathrm{ml}$ )

$c=b^{\prime}$ nin fermente olma hızı (\%)

$\mathrm{t}=$ Zaman (saat)

Fermentasyon sonunda tüpler içerisinde kalan rumen sIVIsında $\mathrm{pH}$, amonyak $\left(\mathrm{NH}_{3}\right)$ ve toplam uçucu yağ asidi (UYA) ile birlikte bireysel olarak uçucu yağ asitleri saptanmıştır. In vitro ortamda fermentasyonla oluşan karbondioksit $\left(\mathrm{CO}_{2}\right)$ ve metan $\left(\mathrm{CH}_{4}\right)$ gazları ise elde edilen rumen sıvılarında yapılan UYA'den yararlanarak aşağıdaki eşitlikler ile hesaplanmıştır (Blümmel ve ark., 1999).

$\mathrm{CO}_{2}=$ asetik asit $(\mathrm{mmol}) / 2+$ propiyonik asit $(\mathrm{mmol}) / 4+$ $1.5 \times$ butirik asit $(\mathrm{mmol})$

$\mathrm{CH}_{4}=($ asetik asit $(\mathrm{mmol})+2 \times$ butirik asit $(\mathrm{mmol}))-\mathrm{CO}_{2}$

in vitro kuru madde gerçek sindirim derecesi ve mikrobiyal protein üretiminin saptanması

Yaklaşık $0.5 \mathrm{~g}$ yem örneği $30 \mathrm{ml}$ çözeltiyle $(10 \mathrm{ml}$ rumen sıVısı $+20 \mathrm{ml}$ yapay tükürük) 100 ml'lik cam şırıngalar içerisinde 24 saat $39{ }^{\circ} \mathrm{C}$ 'de fermentasyona bırakılmıştır (Menke ve ark., 1979). Yirmi dört saatlik fermentasyonun tamamlanmasından sonra şırıngalarda kalan artık kısım beher içerine taşınarak üzerine $50 \mathrm{ml}$ nötral deterjan lif (NDF) çözeltisine ilave edilerek bir saat kaynamaya bırakılmış, daha sonra beher içeriği cam kroze (Grooch 
kroze, porozite: 1)'de süzülmüştür. Gerçek sindirilmiş kuru madde (GSKM) miktarı, kuru madde gerçek sindirim derecesi (KMGSD), mikrobiyal protein üretimi ve taksimat faktörü Blümmel ve ark. (1997)'nın bildirdiği yönteme göre yapılmıştır.

GSKM (mg) = fermentasyona bırakılan KM (mg) - kalan $\mathrm{KM}(\mathrm{mg})$

KMGSD (\%)=(GSKM/ fermentasyona bırakılan KM)

Mikrobiyal protein (MP) $(\mathrm{mg} / \mathrm{g} \mathrm{KM})=$ GSKM $(\mathrm{mg})-(\mathrm{gaz}$ üretimi (GÜ) X $2.2 \mathrm{mg} / \mathrm{ml}$ )

Taksimat Faktörü (PF) = GSKM/GÜ

\section{Kimyasal Analizler}

Yem örneği besin madde içerikleri Isparta Uygulamalı Bilimler Üniversitesi Ziraat Fakültesi Zootekni Bölümü Laboratuvarında AOAC (1990) tarafından bildirilen analiz yöntemine göre, hücre duvarı bileşimi Van Soest ve ark. (1991)'nın bildirdiği deterjan lif analiz yöntemine göre ANKOM 200 Fiber Analyzer (ANKOM Technology)'da analiz edilmiştir. Fermentasyon $\mathrm{pH}$ 'sı dijital $\mathrm{pH}$ metre ile (HANNA HI 221) ile yapılmıştır. Fermentasyon sıvısından $\mathrm{NH}_{3}$ analizi için alınan örnekler, daha sonra analiz yapılmak üzere, doğrudan $-20{ }^{\circ} C^{\prime}$ ye konulurken, UYA'ların analizi için alınan örnekler ise $10 \mathrm{~N} \mathrm{H}_{2} \mathrm{SO}_{4}{ }^{\prime}$ den $100 \mu \mathrm{l}$ eklendikten sonra $-20{ }^{\circ} \mathrm{C}^{\prime}$ ye konulmuştur. Örnekler analiz sırasında $5^{\circ} \mathrm{C}^{\prime}$ de çözdürülmüştür. Örneklerin $\mathrm{NH}_{3}$ konsantrasyonu Kjeldahl metodundan yararlanarak belirlenmiştir (Preston, 1995). Uçucu yă̆ asidi analizi için ayrılan örneklerde 10 dakika 4.000 g'de santrifüj edildikten sonra üstte kalan berrak kısımda uçucu yağ asidi analizi (Galyean, 1989) yapılmıştır. Uçucu yağ asitleri, SDÜ Deneysel ve Gözlemsel Araştırma ve Uygulama Merkezi'nde gaz kromotografisinde (QP-5050 detektörlü Shimadzu 2010 Plus) CP-Wax 52 CB (50 m x
$0.32 \mu \mathrm{mm} .0 .25 \mu \mathrm{m})$ kapiller kolon kullanılarak belirlenmiştir. Enjektör sıcaklığı $240^{\circ} \mathrm{C}$, detektör sıcaklığı $250{ }^{\circ} \mathrm{C}$ olarak ayarlanmış ve helyum gazı taşıyıcı gaz olarak kullanılmıştır.

\section{istatistiksel Analizler}

Araştırma tesadüf parsellerinde 2 (tanen kaynağı) $\times 4$ (tanen dozu) faktöriyel deneme desenine göre planlanmış ve aşağıdaki matematik model kullanılanılmıştır (Düzgüneş ve ark., 1983).

$Y i j k=\mu+\alpha i+\beta j+\alpha \beta i j+\varepsilon i j k$

Yijk = i'inci tanen ekstrakt kaynağının j'inci tanen ekstrakt dozunun 1 'inci gözlem değeri

$\mu=$ genel ortalama

$\alpha i=i^{\prime}$ inci tanen ekstrakt kaynağının etkisi $(i=2$; 1=kestane; 2 = mimoza)

$\beta \mathrm{j}=\mathrm{j}$ 'inci tanen ekstrakt dozunun etkisi $(\mathrm{j}=4 ; 1=0,2=25$ $\mathrm{g}, 3=50 \mathrm{~g}, 4=75 \mathrm{~g} / / \mathrm{kg} \mathrm{KM}$ yem)

$\alpha \beta i j=$ i'inci tanen ekstraktı kaynağı ile j'inci tanen ekstrakt dozları arasındaki interaksiyonun etkisi $\varepsilon \mathrm{ijk}=$ deneme hatası

Araştırmadan elde edilen verilerin ortalamaları arasındaki farklılıkların saptanmasında varyans analizi (General Linear Model-MINITAB), farklılıkların önem düzeylerinin belirlenmesinde ise Duncan çoklu karşılaştırma testinden yararlanılmıştır (Düzgüneş ve ark., 1983).

\section{BULGULAR ve TARTIŞMA}

Araştırmada kullanılan toplam karma rasyonun kimyasal içeriği saptanmış ve Çizelge 1'de verilmiştir.

Çizelge 1. Toplam karma rasyon (TMR)'un kimyasal bileşimi

Table 1. Chemical composition of total mixed ration (TMR)

\begin{tabular}{lc} 
Kuru madde (KM), \% & 90.12 \\
Organik madde, \% KM & 91.47 \\
Ham protein, \% KM & 14.68 \\
Ham kül, \% KM & 8.53 \\
Asit deterjan lif , \% KM & 21.38 \\
Nötral detarjan lif, \% KM & 39.56 \\
\hline
\end{tabular}


Çizelge 2. Mimoza ve kestane tanen ekstraktının farklı dozlarııı in vitro gaz üretimi (ml) ile gaz üretim parametreleri üzerine etkisi

Table 2. Effect of different doses of mimosa and chestnut tannin extract on in vitro gas production (ml) and gas production parameters

\begin{tabular}{|c|c|c|c|c|c|c|c|c|c|c|c|c|}
\hline \multirow{3}{*}{$\begin{array}{l}\text { Tanen } \\
\text { kaynağı }\end{array}$} & \multirow{3}{*}{$\begin{array}{l}\text { Tanen dozu, } \\
\text { g/kg KM }\end{array}$} & \multicolumn{7}{|c|}{ Gaz üretimi (ml) } & \multirow[b]{3}{*}{ a } & \multirow[b]{3}{*}{$b$} & \multirow[b]{3}{*}{ c } & \multirow[b]{3}{*}{$a+b$} \\
\hline & & \multicolumn{7}{|c|}{ İnkübasyon zamanı (saat) } & & & & \\
\hline & & 3 & 6 & 12 & 24 & 48 & 72 & 96 & & & & \\
\hline \multirow{5}{*}{ Mimoza } & 0 & 21.75 & 41.50 & 52.75 & 67.00 & 72.50 & 75.75 & 76.75 & 6.76 & 68.14 & 0.101 & 74.90 \\
\hline & 25 & 20.75 & 40.50 & 51.25 & 63.75 & 70.00 & 73.00 & 74.00 & 6.40 & 65.51 & 0.100 & 71.91 \\
\hline & 50 & 21.50 & 38.25 & 51.75 & 62.25 & 67.75 & 70.75 & 72.00 & 6.05 & 63.84 & 0.103 & 69.89 \\
\hline & 75 & 20.19 & 34.50 & 50.00 & 58.50 & 63.25 & 66.25 & 67.75 & 5.02 & 61.16 & 0.104 & 66.17 \\
\hline & 0 & 21.75 & 41.50 & 52.75 & 67.00 & 72.50 & 75.75 & 76.75 & 6.76 & 68.14 & 0.101 & 74.90 \\
\hline \multirow{5}{*}{\multicolumn{2}{|c|}{ Kestane }} & 22.25 & 38.25 & 54.50 & 66.75 & 72.00 & 75.00 & 76.25 & 5.69 & 68.57 & 0.100 & 74.26 \\
\hline & & 20.75 & 39.75 & 52.50 & 63.50 & 69.00 & 73.25 & 74.50 & 5.33 & 66.57 & 0.103 & 71.90 \\
\hline & & 21.00 & 36.00 & 51.25 & 61.50 & 66.50 & 69.00 & 70.50 & 5.37 & 63.13 & 0.102 & 68.50 \\
\hline & & & & & & & & & 0.557 & 1.470 & 0.001 & 0.094 \\
\hline & & Mimoz & & & & & & & 6.01 & 64.99 & 0.103 & 71.00 \\
\hline \multirow{2}{*}{\multicolumn{2}{|c|}{ Tanen kaynağı }} & Kestane & & & & & & & 5.81 & 67.12 & 0.102 & 72.94 \\
\hline & & $\mathrm{P}$ & & & & & & & 0.62 & 0.04 & 0.75 & 0.07 \\
\hline \multirow{5}{*}{\multicolumn{2}{|c|}{ Tanen dozu }} & 0 & & & & & & & 6.46 & $69.58 a$ & 0.101 & $76.04 a$ \\
\hline & & 25 & & & & & & & 6.04 & $67.04 a$ & 0.100 & 73.08ab \\
\hline & & 50 & & & & & & & 5.69 & $65.20 a b$ & 0.104 & $70.89 b$ \\
\hline & & 75 & & & & & & & 5.45 & $62.41 b$ & 0.102 & $67.86 c$ \\
\hline & & $\mathrm{P}$ & & & & & & & 0.34 & 0.01 & 0.17 & 0.01 \\
\hline \multicolumn{13}{|c|}{ Tanen kaynağı*tanen dozu } \\
\hline & & 0 & & & & & & & 6.76 & 68.15 & 0.101 & 74.91 \\
\hline \multirow{4}{*}{\multicolumn{2}{|c|}{ Mimoza }} & 25 & & & & & & & 6.40 & 65.51 & 0.100 & 71.91 \\
\hline & & 50 & & & & & & & 6.05 & 63.84 & 0.103 & 69.89 \\
\hline & & 75 & & & & & & & 5.02 & 61.16 & 0.104 & 66.18 \\
\hline & & 0 & & & & & & & 6.76 & 68.15 & 0.101 & 74.91 \\
\hline \multirow{4}{*}{\multicolumn{2}{|c|}{ Kestane }} & 25 & & & & & & & 5.69 & 68.57 & 0.100 & 74.26 \\
\hline & & 50 & & & & & & & 5.33 & 66.57 & 0.103 & 71.90 \\
\hline & & 70 & & & & & & & 5.38 & 63.14 & 0.101 & 68.52 \\
\hline & & $\mathrm{P}$ & & & & & & & 0.56 & 0.69 & 0.82 & 0.72 \\
\hline
\end{tabular}

a,b,c,Aynı sütunda farklı harfler ile gösterilen ortalamalar arasındaki farklılıklar önemlidir $(\mathrm{P}<0.05)$.

a : kolay bir şekilde fermantasyona uğramış kısımdan elde edilen gaz miktarı (ml), b : yavaş bir şekilde fermantasyona uğramış kısımdan elde edilen gaz miktarı (ml), c : b'nin fermente olma hızı (\%), a+b:potansiyel gaz üretimi, KM: kuru madde

Mimoza ve kestane tanen ekstraktının farklı dozlarının in vitro gaz üretimi ile gaz üretim parametreleri üzerine etkisi

Mimoza ve kestane tanen ekstraktının farklı dozlarının in vitro gaz üretimi ile gaz üretim parametreleri üzerine etkisi Çizelge 2'de verilmiştir.

$\mathrm{Bu}$ çalışmada en düşük dozda (25 g/kg KM) tanen ekstraktı kullanımının, in vitro gaz üretim parametrelerini etkilememesi $(P<0.05)$ bu seviyede mikrobiyal aktivitenin etkilenmediğini göstermektedir. Daha önce bazı araştırıcılar da (Makkar ve ark., 1995; Waghorn ve Shelton, 1997) rasyonda 50 g/kg KM'nin altında tanen bulunmasının rumen fermentasyon parametrelerini etkilemediğini bildirmektedirler. Buna karşın en yüksek dozda (75 g/kg KM) tanen ekstraktı kullanımının, yavaş bir sekilde fermantasyona uğramış kısımdan elde edilen gaz miktarını düşürmüştür $(P<0.01)$. Tanenler mikroorganizmalarla ve/veya onların enzimleriyle ya da karbonhidratlarla kompleks bileşikler oluşturarak substrat sindirimini düşürmektedir (Bae ve ark., 1993; Jones ve ark., 1994; Nsahlai ve ark., 2011). Karbonhidratların mikrobiyal sindiriminin düşmesi gaz üretimini düşürmektedir. Yapılan bazı çalışmalarda 50 $\mathrm{g} / \mathrm{kg} \mathrm{KM}^{\prime}$ nin üzerinde tanen içeren rasyonların in vitro gaz üretim üretimini azalttığı (Bento ve ark., 2005; Jayanegara ve ark., 2015) bildirilmektedir.

Hidrolize tanenler kondense tanenlere göre daha küçük moleküler ağırlıklı bileşiklerdir. Küçük moleküler ağırlıklı tanenlerin mikroorganizmalar için daha toksik olduğu belirtilmektedir (Patra ve Saxena, 2011). Ancak mevcut çalışmada mimoza tanen ekstraktı kullanımı kestane tanen ekstraktına göre yavaş bir sekilde fermentasyona 
uğramış kısımdan elde edilen gaz miktarını azaltmıştır $(\mathrm{P}=0.04)$. Bu sonuçlar kestane tanendeki hidrolize tanenin bir kısmının mikrobiyal yıkımıyla açıklanabilir. Kondense tanenler mikrobiyal yıkıma dirençli olduğu halde, hidrolize tanenler mikrobiyal olarak kısmen yıkılmaktadır (Field ve Lettinga, 1987; McSweeney ve ark., 2001). Daha önce Cieslak ve ark. (2014) kestane tanen ekstraktının kondense tanence zengin Vaccinium vitis-idaea ekstraktından daha fazla gaz üretimi ürettiğini bulmuşlardır.
Mimoza ve kestane tanen ekstraktının farklı dozlarının rumen fermantasyonuna etkisi

Mimoza ve kestane tanen ekstraktının farklı dozlarının rumen fermentasyonuna etkisi Çizelge 3'de verilmiştir.

Çizelge 3. Mimoza ve kestane tanen ekstraktının farklı dozlarının rumen fermentasyonu üzerine etkileri Table 3. Effects of different doses of mimosa and chestnut tannin extract on rumen fermentation

\begin{tabular}{|c|c|c|c|c|c|c|c|c|c|c|c|}
\hline \multirow{2}{*}{\multicolumn{2}{|c|}{ Etkiler }} & \multirow{2}{*}{$\begin{array}{l}\text { Toplam } \\
\text { UYA } \\
\mathrm{mmol} / \mathrm{L}\end{array}$} & \multicolumn{6}{|c|}{ Uçucu yağ asitleri, mmol/100mmol } & \multirow[b]{2}{*}{$\mathrm{C}_{2} / \mathrm{C}_{3}$} & \multirow[b]{2}{*}{$\mathrm{pH}$} & \multirow{2}{*}{$\begin{array}{l}\mathrm{NH}_{3} \mathrm{~N} \\
\mathrm{mg} / \mathrm{dL}\end{array}$} \\
\hline & & & $\mathrm{C}_{2}$ & $\mathrm{C}_{3}$ & $\mathrm{C}_{4}$ & $i_{s o C_{4}}$ & $\mathrm{C}_{5}$ & $i_{\text {iso }} \mathrm{C}_{5}$ & & & \\
\hline \multicolumn{12}{|c|}{ Tanen kaynağı } \\
\hline Mimoza & & 123.25 & 51.32 & $20.85 a$ & 17.99 & 2.91 & 3.25 & 3.59 & 2.55 & 6.52 & $27.87 b$ \\
\hline Kestane & & 126.00 & 51.98 & $19.61 b$ & 18.18 & 3.12 & 3.29 & 3.79 & 2.67 & 6.47 & $29.96 a$ \\
\hline SEM & & 1.129 & 0.508 & 0.422 & 0.322 & 0.096 & 0.094 & 0.114 & 0.053 & 0.026 & 0.304 \\
\hline $\mathrm{P}$ & & 0.09 & 0.17 & 0.01 & 0.39 & 0.07 & 0.72 & 0.16 & 0.07 & 0.23 & 0.01 \\
\hline \multicolumn{12}{|c|}{ Tanen dozu, g/kg KM } \\
\hline 0 & & 128.50a & $52.74 a$ & $18.12 \mathrm{c}$ & 18.52 & $3.17 a$ & 3.45 & 3.98ab & $2.92 \mathrm{a}$ & 6.43 & $33.20 \mathrm{a}$ \\
\hline 25 & & $126.75 a$ & $52.97 a$ & $18.19 c$ & 18.24 & $3.16 a$ & 3.24 & $4.11 a$ & $2.82 a$ & 6.45 & $30.59 b$ \\
\hline 50 & & 124.38ab & $51.15 a b$ & $21.15 b$ & 17.91 & $3.05 a b$ & 3.38 & $3.48 \mathrm{bc}$ & $2.47 b$ & 6.54 & $27.77 c$ \\
\hline 75 & & $118.88 \mathrm{~b}$ & $49.76 b$ & $23.47 a$ & 17.67 & $2.67 b$ & 3.02 & $3.28 c$ & $2.23 b$ & 6.55 & $23.60 d$ \\
\hline SEM & & 1.597 & 0.890 & 0.597 & 0.455 & 0.137 & 0.133 & 0.162 & 0.076 & 0.037 & 0.429 \\
\hline $\mathrm{P}$ & & 0.01 & 0.01 & 0.01 & 0.06 & 0.01 & 0.07 & 0.01 & 0.01 & 0.08 & 0.01 \\
\hline \multicolumn{12}{|c|}{ Tanen kaynağı*tanen dozu } \\
\hline & 0 & 128.50 & 52.74 & 18.12 & 18.52 & 3.17 & 3.45 & 3.98 & 2.92 & 6.43 & $33.20 a$ \\
\hline \multirow{4}{*}{ Mimoza } & 25 & 126.25 & 52.07 & 19.03 & 18.41 & 3.88 & 3.32 & 3.99 & 2.78 & 6.48 & $29.56 b$ \\
\hline & 50 & 123.00 & 51.06 & 21.66 & 17.70 & 3.43 & 3.41 & 3.28 & 2.41 & 6.58 & $26.60 \mathrm{~cd}$ \\
\hline & 75 & 115.25 & 49.45 & 24.59 & 17.32 & 2.99 & 2.83 & 3.11 & 2.08 & 6.56 & $21.60 \mathrm{e}$ \\
\hline & 0 & 128.50 & 52.74 & 18.12 & 18.52 & 3.17 & 3.45 & 3.98 & 2.92 & 6.43 & $33.20 a$ \\
\hline \multirow[t]{3}{*}{ Kestane } & 25 & 127.25 & 53.88 & 17.33 & 18.08 & 3.26 & 3.16 & 4.23 & 2.85 & 6.41 & $31.62 \mathrm{ab}$ \\
\hline & 50 & 125.75 & 51.24 & 20.63 & 18.11 & 3.29 & 3.36 & 3.69 & 2.54 & 6.50 & $28.94 b c$ \\
\hline & 75 & 122.50 & 50.07 & 22.35 & 18.02 & 2.75 & 3.21 & 3.27 & 2.37 & 6.53 & $25.60 d$ \\
\hline SEM & & 2.259 & 1.258 & 0.845 & 0.644 & 0.193 & 0.188 & 0.229 & 0.107 & 0.053 & 0.607 \\
\hline $\mathrm{P}$ & & 0.41 & 0.53 & 0.23 & 0.51 & 0.45 & 0.39 & 0.78 & 0.43 & 0.84 & 0.02 \\
\hline
\end{tabular}

$\overline{a, b, c, d, e}$ Aynı sütunda farklı harfler ile gösterilen ortalamalar arasındaki farklııklar önemlidir $(P<0.05)$.

UYA: uçucu yağ asidi, $\mathrm{C}_{2}$ : asetik asit, $\mathrm{C}_{3}$ :propiyonik asit, $\mathrm{C}_{4}$ : butirik asit, $\mathrm{C}_{5}$ : valerik asit, $\mathrm{NH}_{3} \mathrm{~N}$ : amonyak $\mathrm{N}, \mathrm{KM}$ :kuru madde

Rasyona en düşük dozda ( $25 \mathrm{~g} / \mathrm{kg} \mathrm{KM}$ ) tanen ekstraktı ilavesi toplam UYA üretimini etkilememesine ( $P>0.05)$ rağmen, en yüksek dozun (75 $\mathrm{g} / \mathrm{kg} \mathrm{KM})$ toplam UYA miktarını düşürmesi $(P<0.01)$; tanenlerin rumen mikroorganizmaları üzerine antimikrobiyal etkilerinin kullanılan dozla ilişkili olduğu sonucunu göstermektedir. Hassanat ve Benchaar (2013) hidrolize ve kondense tanenlerin $50 \mathrm{~g} / \mathrm{kg} \mathrm{KM}$ 'den daha yüksek düzeylerde rasyona ilavesinin toplam UYA üretimi düşürme eğilimine yönelttiğini saptamışlardır. Rumen sıvısına 25 $\mathrm{g} / \mathrm{kg} \mathrm{KM}$ tanen ekstraktı ilavesi UYA bileşenleri üzerine etkili olmamıştır $(P>0.05)$. Poncet ve R'emond (2002) ve Krueger ve ark. (2010) rasyona 24 g/kg KM 'ye kadar kestane tanen ekstraktı ilavesinin asetik, propiyonik ve 
bütirik asit üretimini etkilemediğini saptamışlardır. Buna karşın Carulla ve ark. (2005) ve Hess ve ark. (2006) koyun rasyonlarına kondense tanen kaynağı olarak akasya tanen ilavesinin asetik asit üretimini düşürdüğünü, propiyonik asit üretimini ise artırdığını bulmuşlardır. Rumen sıvısına $75 \mathrm{~g} / \mathrm{kg} \mathrm{KM}$ tanen ekstraktı ilavesi propiyonik asit düzeyini artırmış $(\mathrm{P}<0.01)$, asetik asit ve iso asitlerini düşürmüş $(\mathrm{P}<0.01)$, bütirik ve valerik asitlerini düşürme eğilimine $(P=0.06)$ sokmuştur. Benzer şekilde Khiaosa-Ard ve ark. (2009) rumen sıvısına 79 g/kg KM akasya tanen ilavesinin asetik/propiyonik asit oranını düşürdüğünü bildirmektedirler. Rumende selülotik mikroorganizmalar genellikle asetik ve bütirik asit üretmektedirler (Stewart, 1991). Bu yüzden mevcut araştırmada çoğunlukla selülotik mikroorganizmaların etkilendiği söylenebilir. Jayanegara ve ark. (2015) rumen sıvısına artan düzeylerde mimoza ya da kestane tanen ilavesinin Fibrobacter succinogenes ve Ruminococcus flavefaciens gibi selülotik bakteriler ile anaerobik fungusların sayısının paralel olarak azaldığını saptamışlardır. Nelson ve ark. (1997) tanenlerin Fibrobacter succinogenes türü selülotik bakterilerin aktivitelerini Prevotella ruminicola ve Streptococcus bovis gibi amilolitik bakterilerin aktivitelerine göre daha çok etkilediklerini bulmuşlardır. Mevcut çalışmada mimoza tanen ekstraktı kullanımı toplam UYA miktarı $(\mathrm{P}=0.09)$ ile isobütirik asiti $(\mathrm{P}=0.07)$ kestane tanen ekstraktına göre düşürme eğilimine yöneltirken, propiyonik asit düzeyini artırması $(\mathrm{P}<0.01)$ özellikle yüksek konsantrasyonda kondense tanenlerin hidrolize tanenlere göre selülotik mikroorganizmalar üzerinde daha etkili bir antimikrobiyal olduğuyla açıklanabilir. Jayanegara ve ark. (2015) rumen sıvisına kestane tanen ektraktı ilavesinin mimoza tanen ekstraktına göre toplam UYA üretimindeki azalmanın daha düşük olduğunu bulmuşlardır. Min ve ark. (2014) meradaki keçi rasyonlarına günde $100 \mathrm{~g}$ kestane tanen ekstraktı ilavesinin kondense tanen ekstraktı ilavesine göre daha fazla toplam UYA üretimi gerçekleştiğini saptamışlardır. Hassanat ve Benchaar (2013)'a göre hidrolize tanenler asetatik/propiyonik asit oranını ekilememesine rağmen, kondense tanenler düşürmektedirler. En düşük dozda ( $25 \mathrm{~g} / \mathrm{kg} \mathrm{KM}$ ) tanen ekstraktı kullanımının rumen $\mathrm{pH}^{\prime}$ sını etkilememesine rağmen, 50 ve $75 \mathrm{~g} / \mathrm{kg} \mathrm{KM}$ tanen ekstraktı ilavesiyle artış eğilimi ( $P=0.08)$, asetik ve bütirik asit üretimi ile toplam UYA miktarındaki azalış eğilimi ve propiyonik asit üretimindeki artış ile açıklanabilir (Çizelge 3). Bu bulgular hidrolize ve kondense tanenler ile çalışan Hassanat ve Benchaar (2013)'nın bildirdikleri sonuçlarla da uyum içinde bulunmuştur. Tanenler proteinlerle kompleks bileşikler oluşturarak ya da mikroorganizmalarla ve/veya onların proteaz enzimleriyle rumende amonyak seviyesinin azalmasına neden olmaktadır. Rumende oluşan protein-tanen kompleksi abomasumda ( $\mathrm{pH}$ 2.5-3.5) ve ince barsakta (pH 8.0) kendini oluşturan birimlere parçalanmaktadır. Serbest kalan proteinler ince barsakta emilime uğramaktadır (Patra ve Saxena, 2011). Mevcut araştırmada rumen sıvısına bütün seviyelerde tanen ekstraktı ilavesi rumende amonyak seviyesini düşürmüştür $(P<0.01)$. Hassanat ve Benchaar (2013) rumen sıvısına $20 \mathrm{~g} / \mathrm{kg} \mathrm{KM}$ akasya yada kestane tanen ekstraktı ilavesinin amonyak oranını düşürdüğünü bildirmektedirler. Rumende amino asitlerin deaminasyonunun azalması da rumende amonyak seviyesinin azalmasına katkıda bulunmaktadır. Rumen sıvısına $75 \mathrm{~g} / \mathrm{kg} \mathrm{KM}$ tanen ekstraktı ilavesinin iso asitleri düşürmesi $\quad(\mathrm{P}<0.01) \quad$ deaminasyonun azalışıla açıklanabilir. Mevcut araştırmada toplam UYA ve UYA bileşenleri ile karşılaştırıldı̆̆ında amonyak düzeyi daha fazla etkilenmiştir. Bu sonuç tanenlerin proteinlerle karbonhidratlardan daha fazla bileşik oluşturma eğilimiyle açıklanabilir (Min ve ark., 2003). Tanenlerin moleküler ağırlığı arttıkça proteinlerle bileşik oluşturma kapasitesi düşmektedir (Hagerman ve Butler, 1989). Ancak mevcut çalışmada mimoza tanen ekstraktı kullanımıyla kestane tanen ekstraktı göre $\mathrm{NH}_{3}{ }^{\prime}$ । düşürmüş $(P<0.01)$, isobütürik asidi düşürme eğilimine yöneltmiştir $(P=0.07)$. Bu sonuçlar hidrolize tanenprotein kompleksinin bir kısmının mikrobiyal enzimlerle yıkımıyla açıklanabilir. Kondense tanen-protein kompleksi mikrobiyal yıkıma dirençli olduğu halde (McSweeney ve ark., 1999), hidrolize tanen-protein kompleksi mikrobiyal olarak kısmen yıkılmaktadır (Patra ve Saxena, 2011).

\section{Mimoza ve kestane tanen ekstraktının farklı dozlarının in vitro kuru madde gerçek sindirim derecesi ve mikrobiyal protein üretimi üzerine etkisi}

Mimoza ve kestane tanen ekstraktının farklı dozlarının in vitro kuru madde gerçek sindirim derecesi ve mikrobiyal protein üretimi üzerine etkisi Çizelge 4'de verilmiştir.

Bu çalışmada $75 \mathrm{~g} / \mathrm{kg} \mathrm{KM}$ dozda tanen ekstraktı kullanımı in vitro kuru madde gerçek sindirim derecesini azaltmış $(P<0.01)$, mimoza tanen ekstraktı kullanımı kestane tanen ekstraktına göre düşürme eğilimine yöneltmiştir $(P=0.09)$. Daha önce Jayanegara ve ark. (2015) kestane ya da sumak gibi hidrolize tanenler ile akasya yada quebracho tanen gibi kondense tanenlerin artan dozlariyla $(0.5,0.75$ ve $1.0 \mathrm{mg} / \mathrm{ml})$ in vitro kuru madde sindirilebilirliğinde quadratik bir azalma saptamışlardır. Azalma kondense tanenlerde daha fazla olmuştur. Makkar ve ark. (1995) kondense tanenlerin yemlerin in 
vitro sindirilebilirliğini hidrolize tanenlere göre daha fazla

düşürdüğünü bulmuşlardır.

Çizelge 4. Mimoza ve kestane tanenin farklı dozlarının in vitro kuru madde gerçek sindirim derecesi ve mikrobiyal protein üretimi üzerine etkileri

Table 4. Effects of different doses of mimosa and chestnut tannin extract on in vitro true dry matter digestibility and microbial protein production

\begin{tabular}{|c|c|c|c|c|}
\hline \multicolumn{2}{|l|}{ Etkiler } & KMGSD, \% & MPÜ, g & $\mathrm{PF}$ \\
\hline \multicolumn{5}{|l|}{ Tanen kaynağı } \\
\hline \multicolumn{2}{|l|}{ Mimoza } & 70.66 & 130.72 & 3.70 \\
\hline \multicolumn{2}{|l|}{ Kestane } & 72.38 & 132.47 & 3.67 \\
\hline \multicolumn{2}{|l|}{ SEM } & 0.692 & 2.105 & 1.028 \\
\hline \multicolumn{2}{|l|}{$\mathrm{P}$} & 0.09 & 0.62 & 0.68 \\
\hline \multicolumn{5}{|l|}{ Tanen dozu , g/kg KM } \\
\hline \multicolumn{2}{|l|}{0} & 74.48a & 129.80 & $3.55 b$ \\
\hline \multicolumn{2}{|l|}{25} & 73.46ab & 133.97 & $3.66 a b$ \\
\hline \multicolumn{2}{|l|}{50} & $70.87 a b$ & 133.38 & $3.74 a b$ \\
\hline \multicolumn{2}{|l|}{75} & $67.26 b$ & 129.25 & $3.79 a$ \\
\hline \multicolumn{2}{|l|}{ SEM } & 0.978 & 2.976 & 1.453 \\
\hline \multicolumn{2}{|l|}{$\mathrm{P}$} & 0.01 & 0.70 & 0.04 \\
\hline \multicolumn{5}{|c|}{ Tanen kaynağı* tanen dozu } \\
\hline & 0 & 74.48 & 129.80 & 36.39 \\
\hline & 25 & 72.62 & 132.85 & 32.66 \\
\hline \multirow[t]{4}{*}{ Mimoza } & 50 & 69.40 & 134.35 & 30.96 \\
\hline & 75 & 63.39 & 125.90 & 25.82 \\
\hline & 0 & 74.48 & 129.80 & 36.39 \\
\hline & 25 & 74.31 & 135.10 & 34.53 \\
\hline \multirow[t]{2}{*}{ Kestane } & 50 & 71.25 & 132.40 & 33.16 \\
\hline & 75 & 66.66 & 132.40 & 28.88 \\
\hline SEM & & 1.235 & 3.878 & 2.009 \\
\hline $\mathrm{P}$ & & 0.68 & 0.83 & 0.88 \\
\hline
\end{tabular}

$\overline{a, b}$ Aynı sütunda farklı harfler ile gösterilen ortalamalar arasındaki farklılıklar önemlidir $(P<0.05)$.

KMGSD: in vitro kuru madde gerçek sindirim derecesi, MPÜ: mikrobiyal protein üretimi, PF: taksimat faktörü, KM:kuru madde

Mikrobiyal protein üretimi tanen ekstraktı kaynağı ve dozundan etkilenmemiştir $(P>0.05)$. Yemlerin PF değerinin mikrobiyal protein sentezleme etkinliğini gösteren önemli bir gösterge olduğu ve PF değeri yüksek olan yemlerin mikrobiyal protein sentezleme etkinliğinin de yüksek olduğu bildirilmektedir (Blümmel ve Lebzien, 2001). Mevcut çalışmada rumen sıvısına tanen ekstraktı kullanımıyla PF değerleri yükselme eğilimi göstermiş, 75 $\mathrm{g} / \mathrm{kg}$ KM dozda tanen ekstraktı kullanımı kontrolden farklı bulunmuştur $(P<0.05)$. Yapılan bazı çalışmalarda da rasyonlarda tanen kullanımıyla $\mathrm{PF}$ faktörün artma eğilimine yöneldiği görülmüştür (Baba ve ark., 2002; Getachew ve ark., 2000; Makkar ve ark., 1995).
Mimoza ve kestane tanen ekstraktının farklı dozlarının karbondioksit ve metan gazı üretimine etkisi

Mimoza ve kestane tanen ekstraktının farklı dozlarının $\mathrm{CO}_{2}$ ve metan $\mathrm{CH}_{4}$ gazı üretimi üzerine etkileri saptanmış ve Çizelge $5^{\prime}$ de verilmiştir. Rumen SIVISı UYA'lerinden yararlanarak saptanan $\mathrm{CO}_{2}$ gazı üretimi tanen ekstraktı dozuna bağlı olarak önemli düzeyde azalmıştır $(P<0.01)$. Metan gazı üretimi ise $25 \mathrm{~g} / \mathrm{kg} \mathrm{KM}$ doz hariç artan dozla önemli derecede düşmüştür $(P<0.01)$. Beauchemin ve ark. (2007) rasyona $25 \mathrm{~g} / \mathrm{kg} \mathrm{KM}$ 'ye kadar quebracho tanen ekstraktı ilavesinin metan salınımını etkilemediğini bulmuşlardır. Jayanegara ve ark. (2012) in vivo ve in vitro araştırmalara dayalı bir meta analiz sonunda, rasyondaki tanen oranının \% 17'ye kadar artışıla, artan tanen oranıyla metan salınımının doğrusal olarak düştüğü 
sonucuna varmışlardır. Genel olarak tanenlerin metan üretimindeki düşürücü etkisi tanenlerin metanojenlere direkt toksik etkisinden kaynaklanmaktadır. Jayanegara ve ark. (2009) $1 \mathrm{mg} / \mathrm{ml}$ quebracho, mimoza ve kestane tanen ekstraktı içeren rasyonlarda metanojen sayılarının sırasıyla \% 24, 29 ve 37 oranında düştüğünü saptamışlardır. Tanenler ayrıca yem organik madde sindirimi ile selüloz sindirimini düşürerek toplam UYA, asetik ve bütirik asit üretimini azaltmak yoluyla metan üretimindeki düşüşe katkıda bulunmaktadır. Mevcut araştırmada metan üretimindeki azalma; asetik ve bütirik asit ile toplam UYA miktarındaki azalış ile propiyonik asit üretimindeki artışa bağlanabilir. Mimoza tanen ekstraktıyla metan üretimindeki azalma kestane tanen ekstraktından daha fazla olmuştur. Bu duruma propiyonik asit oranındaki artış, asetik ve bütirik asit üretimindeki sayısal düşüş ile toplam UYA miktarındaki azalış eğilimi sebep olmuştur. Field ve Lettinga (1987) tanenlerin kaynağı ve dozunun onların antimetanojenik aktivitelerini etkilediğini bildirmektedirler.

Çizelge 5. Mimoza ve kestane tanenin farklı dozlarının karbondioksit ve metan gazı üretimi üzerine etkileri

Table 5. Effects of different doses of mimosa and chestnut tannin extract on carbon dioxide and methane gas production

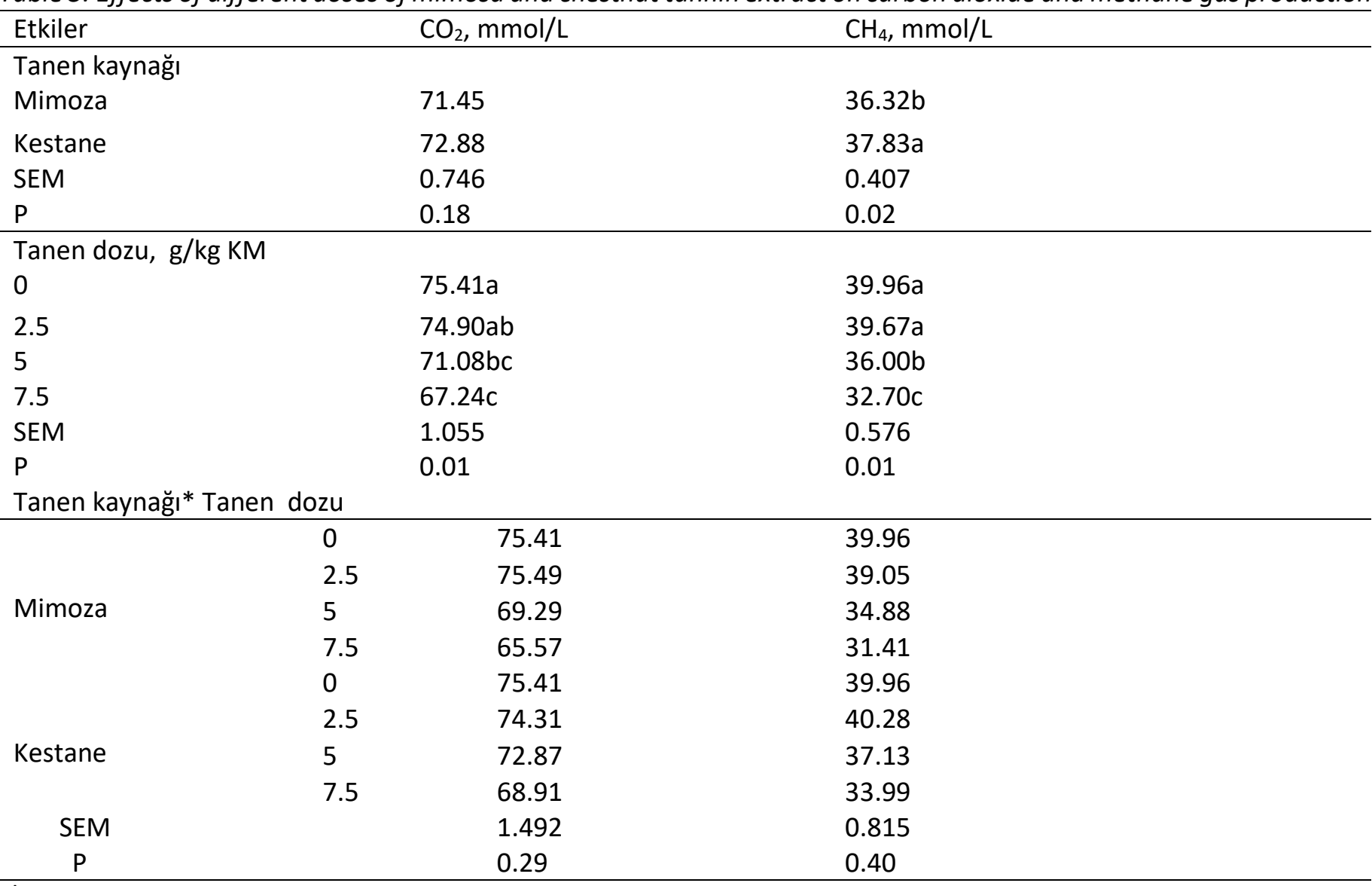

$\overline{a, b, c}$ Aynı sütunda farklı harfler ile gösterilen ortalamalar arasındaki farklılıklar önemlidir ( $\mathrm{P}<0.05)$.

$\mathrm{CO}_{2}$ : karbondioksit, $\mathrm{CH}_{4}$ : metan, $\mathrm{KM}$ :kuru madde

Sonuç olarak; yemlere kestane ve mimoza tanen ekstraktı ilavesinin in vitro gaz üretimi, kuru madde sindirimi ve rumen fermentasyonu üzerine etkileri tanen kaynağı ve dozundan etkilenmektedir. Rumen sıvısına 25 $\mathrm{g} / \mathrm{kg} \mathrm{KM}$ tanen ekstraktı ilavesi $\mathrm{NH}_{3}$ hariç fermentasyon parametreleri üzerinde etkili olmamaktadır. Rasyona 75 $\mathrm{g} / \mathrm{kg}$ KM tanen ekstraktı ilavesi asetik/ propiyonik asit oranı, $\mathrm{NH}_{3}$ düzeyi ile $\mathrm{CH}_{4}$ gazı üretimini önemli düzeyde azaltmasına rağmen, toplam UYA üretimini olumsuz yönde etkilemektedir. Bu yüzden rasyondaki tanen konsantrasyonu $50 \mathrm{~g} / \mathrm{kg}$ KM’ı geçmemelidir. Mimoza tanen ekstraktının amonyak ve metan üretimindeki düşürücü etkisi kestane tanen ekstraktından daha yüksektir. Ancak mevcut bulgular yapılacak in vivo çalışmalarla desteklenmelidir.

\section{ÖZET}

Amaç: $\mathrm{Bu}$ araştırmada; mimoza ve kestane tanen ekstraktı ilavesinin rumen fermentasyonu üzerine olan etkilerinin incelenmesi amaçlanmıştr.

Yöntem ve Bulgular: Rumen sıvısına 0, 25, 50 ve 75 g/kg kuru madde (KM) dozlarında mimoza ve kestane tanen 
ekstraktı ilavesinin in vitro gaz üretimi, kuru madde sindirilebilirliği, mikrobiyal protein üretimi ile rumen fermentasyonu üzerine olan etkileri incelenmiştir. Rumen sıvısına $25 \mathrm{~g} / \mathrm{kg}$ KM tanen ekstraktı ilavesi amonyak $\left(\mathrm{NH}_{3}\right)$ hariç fermentasyon parametreleri üzerinde etkili olmamıştır $(P>0.05)$. Buna karşın rumen sıvısına $75 \mathrm{~g} / \mathrm{kg}$ KM tanen ekstraktı ilavesi yavaş bir sekilde fermentasyona uğramış kısımdan elde edilen gaz miktarı, potansiyel gaz üretimi ve rumen sIVISI parametrelerinden toplam uçucu yağ asitleri (UYA), asetik asit, butirik asit, asetik/ propiyonik asit oranı, $\mathrm{NH}_{3}$ düzeyi ile karbondioksit $\left(\mathrm{CO}_{2}\right)$ ve metan $\left(\mathrm{CH}_{4}\right)$ gazı üretimini önemli düzeyde azaltmıştır $(P<0.01)$. Kestane tanen ekstrakt ilavesiyle karşılaştırıldığında mimoza tanen ekstrakt ilavesi $\mathrm{NH}_{3}$ düzeyi $(P<0.01)$, yavaş bir sekilde fermantasyona uğramış kısımdan elde edilen gaz miktarı ile $\mathrm{CH}_{4}$ miktarıını düşürmüş $(\mathrm{P}<0.05)$, propiyonik asit miktarını artırmış $(\mathrm{P}<0.01)$, toplam UYA, isobütirik asit, kuru maddenin gerçek sindirim derecesi ile asetik/propiyonik asit oranını ise düşürme eğilimine yöneltmiş̧ir ( $\mathrm{P}>0.05)$.

Genel Yorum: Sonuç olarak, ruminant beslemede 50 g/kg KM'a kadar tanen ekstraktının rasyonda kullanılmasının uygun olacağı, daha yüksek dozda kullanılması durumunda rumen fermentasyonu ve yemden yararlanmayı olumsuz etkileyebileceği, mimoza tanen ekstraktının $\mathrm{NH}_{3}$ ve $\mathrm{CH}_{4}$ üretimindeki düşürücü etkisinin kestane tanen ekstraktından daha yüksek olduğu söylenebilir.

Çalışmanın Önemi ve Etkisi: Tanenler kaynağı ve dozuna bağlı olarak, mikrobiyal fermentasyon ve rasyon sindirilebilirliğini düşürebilir. Buna karşın kestane yada mimoza tanen ruminant rasyonlarına uygun düzeylerde katıldığı zaman, ruminal fermentasyon olumsuz etkilenmeksizin $\mathrm{CH}_{4}$ ve $\mathrm{NH}_{3}$ salınımının düşürülmesine yardımcı olabilir.

Anahtar Kelimeler: Tanen ekstraktı, yem, in vitro rumen fermentasyon

\section{TEŞEKKÜR}

Bu çalışma Süleyman Demirel Üniversitesi Bilimsel Araştırma Projeleri Komisyonu (BAP) tarafından desteklenen SDUBAP 4008-YL1-14' nolu projenin bir bölümünü içermektedir. Projeyi destekleyen SDÜBAP Komisyonu Başkanlığı'na teşekkür ederiz.

\section{ÇIKAR ÇATIŞMA BEYANI}

Yazarlar çalışma konusunda çıkar çatışmasının olmadığını beyan eder.

\section{KAYNAKLAR}

AOAC (1990) Association of Official Analytical Chemists. Official methods of analysis. 15th ed., Vol. 1, AOAC, Washington, DC, pp. 69-79.

Baba ASH, Castro FB, Ørskov ER (2002) Partitioning of energy and degradability of browse plants in vitro and the implications of blocking the effects of tannin by the addition of polyethylene glycol. Anim. Feed Sci. Technol. 95: 93-104.

Bae HD, McAllister TA, Yanke J, Cheng K-J, Muir AD (1993) Effects of condensed tannins on endoglucanase activity and filter paper digestion by Fibrobacter succinogenes S85. Appl. Environ. Microbiol. 59: 2132-2138.

Beauchemin KA, McGinn SM, Martinez TF, McAllister TA (2007) Use of condensed tannin extract from quebracho trees to reduce methane emissions from cattle. J. Anim. Sci. 85: 1990-1996.

Bento MHL, Makkar HPS, Acamovic T (2005) Effect of mimosa tannin and pectin on microbial protein synthesis and gas production during in vitro fermentation of $15 \mathrm{~N}$-labelled maize shoots. Anim. Feed Sci. Technol. 123-124:365-377.

Blümmel M, Makkar HPS, Becker K (1997) In vitro gas production- A technique revised. J. Anim. Physiol. Anim. Nutr. 77: 24-34.

Blümmel M, Aiple KP, Steingass H, Becker K (1999) A note on the stoichiometrical relationship of short chain fatty acid production and gas evolution in vitro in feedstuffs of widely differing quality. J. Anim. Physiol. Anim. Nutr. 81: 157-167.

Blümmel M, Lebzien $P$ (2001) Predicting ruminal microbial efficiencies of dairy rations by in vitro techniques. Liv. Prod. Sci. 68(2-3): 107-117.

Carulla JE, Kreuzer M, Machmuller A, Hess HD (2005) Supplementation of Acacia mearnsii tannins decreases methanogenesis and urinary nitrogen in forage-fed sheep. Aust. J. Agric. Res. 56:961-970.

Cieslak A, Zmora P, Pers-Kamczyc E, Stochmal A, Sadowinska A, Salem AZ, Szumacher-Strabel M (2014) Effects of two sources of tannins (Quercus L. and Vaccinium vitis idaea L.) on rumen microbial fermentation: an in vitro study. Ital. J. Anim. Sci. 13(2): 290-294.

Düzgüneş $O$, Kesici T, Gürbüz $F$ (1983) İstatistik Metodları, A.Ü. Yayınları, A831, Ankara.

Field JA, Lettinga G (1987) The methanogenic toxicity and anaerobic degradability of hydrolysable tannins. Water Res. 21: 367-374. 
Galyean M (1989) Laboratory Procedure in Animal Nutrition Research, Department of Animal and Range Sciences, New Mexico State University,USA.

Getachew G, Makkar HPS, Becker K (2000) Effect of polyethylene glycol on in vitro degradability of nitrogen and microbial protein synthesis from tanninrich browse and herbaceous legumes. Brit. J. Nutr. 84: 73-83.

Hassanat F, Benchaar C (2013) Assessment of the effect of condensed (acacia and quebracho) and hydrolysable (chestnut and valonea) tannins on rumen fermentation and methane production in vitro. J.Sci. Food Agric. 93(2): 332-339.

Hagerman AE, Butler LG (1989) Choosing appropriate methods and standards for assaying tannins. J. Chem. Ecol. 11:1535-1544.

Hess HD, Tiemann TT, Noto F, Carulla JE, Kreuzer M (2006) Strategic use of tannins as means to limit methane emission from ruminant livestock. Int. Congr. Ser. 1293:164-167.

Jayanegara A, Makkar HPS, Becker K (2009) Methane reducing properties of polyphenol containing plants simple phenols and purified tannins in in vitro gas production method, FAO-IAEA International Symposium 'Sustainable Improvement of Animal Production and Health', 8 to 11 June 2009, Vienna, Austria. pp 92-93.

Jayanegara A, Leiber F, Kreuzer M (2012) Meta-analysis of the relationship between dietary tannin level and methane formation in ruminants from in vivo and in vitro experiments. J. Anim. Physiol. Anim. Nutr. 96:365-375.

Jayanegara A, Goel G, Makkar HP, Becker K (2015) Divergence between purified hydrolysable and condensed tannin effects on methane emission, rumen fermentation and microbial population in vitro. Anim. Feed Sci. Technol. 209:60-68.

Jones GA, McAllister TA, Muir AD, Cheng KJ (1994) Effects of sainfoin (Onobrychis viciifolia Scop.) condensed tannins on growth and proteolysis by four strains of ruminal bacteria. Appl. Environ. Microbiol. 60: 1374-1378.

Khiaosa-Ard R, Bryner SF, Scheeder MRL, Wettstein HR, Leiber F, Kreuzer M (2009) Evidence for the inhibition of the terminal step of ruminal $\alpha$-linolenic acid biohydrogenation by condensed tannins. J. Dairy Sci. 92:177-188.
Krueger WK, Gutierrez-Banuelos H, Carstens GE, Min BR, Pinchak WE, Gomez RR (2010) Effects of dietary tannin source on performance, feed efficiency, ruminal fermentation, and carcass and non-carcass traits in steers fed a high-grain diet. Anim. Feed Sci. Technol. 159:1-9.

Lowry JB, McSweeney CS, Palmer B (1996) Changing perceptions of the effect of plant phenolics on nutrient supply in the ruminant. Aust. J. Agric. Res. 47: 829-842.

Makkar HPS, Blümmel M, Becker K (1995) In vitro effects of and interactions between tannins and saponins and the fate of tannins in the rumen. J.Sci. Food Agric. 69: 481-493.

McSweeney CS, Palmer B, Bunch R, Krause DO (1999) Isolation and characterization of proteolytic ruminal bacteria from sheep and goats fed the tannincontaining shrub legume Calliandra calothyrsus. J. Appl. Environ. Microbiol. 65:3075-3083.

McSweeney CS, Palmer B, McNeil DM, Krause DO (2001) Microbial interactions with tannins: nutritional consequences for ruminants. Anim. Feed Sci. Technol. 91: 83-93.

Menke KH, Raab L, Salewski A, Steingass H, Fritz D, Schneider W (1979) The estimation of the digestibility and metabolizable energy content of ruminant feedingstuffs from the gas production when they are incubated with rumen liquor in vitro. J. Agr. Sci. 93 (1): 217-222.

Min BR, Barry TN, Attwood GT, McNabb WC (2003) The effect of condensed tannins on the nutrition and health of ruminants fed fresh temperate forages: a review. Anim. Feed Sci. Technol. 106:3-19.

Min B, Wright C, Ho P (2014) The effect of phytochemical tannins containing diet on rumen fermentation characteristics and microbial diversity dynamics in goats using 16S rDNA amplicon pyrosequencing. Agric. Food Anal. Bacteriol. 4:195-211.

MINITAB (1996) MINITAB Release 11 for Windows, State College, Pennsylvania, USA.

Nelson KE, Pell AN, Doane PH, Giner-Chavez BI, Schofield $P$ (1997) Chemical and biological assays to evaluate bacterial inhibition by tannins. J. Chem. Ecol. 23: 1175-1194.

Nsahlai I, Fon F, Basha N (2011) The effect of tannin with and without polyethylene glycol on in vitro gas production and microbial enzyme activity. S. Afr. J. Anim. Sci. 41:337-344.

Orskov ER, McDonald I (1979) The estimation of protein degradability in the rumen from incubation measurements weighted according to rate of passage. J. Agr. Sci. 92: 499-503. 
Patra AK, Saxena J (2011) Exploitation of dietary tannins to improve rumen metabolism and ruminant nutrition. J. Sci. Food Agric. 91:24-37.

Poncet C, R'emond D (2002) Rumen digestion and intestinal nutrient flows in sheep consuming pea seeds: the effect of extrusion or chestnut tannin addition. Anim. Res. 51:201-216.

Preston TR (1995) Biological and chemical analytical methods. In: Tropical Animal Feeding: A Manual for Research Workers. (Eds Preston TR), FAO, Rome, pp. 191-264.

Reed JD (1995) Nutritional toxicology of tannins and related polyphenols in forage legumes. J. Anim. Sci. 73: 1516-1528.
Stewart CS (1991) The rumen bacteria. In: Rumen Microbial Metabolism and Ruminant Digestion. (Eds Jouany JP), INRA ed, Paris, France, pp. 15-26.

Tabacco E, Borreani G, Crovetto GM, Galassi G, Colombo D, Cavallarin L (2006) Effect of chestnut tannin on fermentation quality, proteolysis, and protein rumen degradability of alfalfa silage. J. Dairy Sci. 89:47364746.

Waghorn GC, Shelton ID (1997) Effect of condensed tannins in Lotus corniculatus on the nutritive value of pasture for sheep. J. Agric. Sci. 128: 365-372.

Van Soest PJ, Robertson JB, Lewis A (1991) Methods for dietary fiber, neutral detergent fiber, and nonstarch polysaccharides in relation to animal nutrition. J. Dairy Sci. 74: 3583-3597. 